See Article page 40.

\section{Commentary: The devil is in the details}

\author{
Matheus P. Falasa, MD, ${ }^{\mathrm{a}}$ and \\ Thomas M. Beaver, MD, MPH
}

Ishii and colleagues ${ }^{1}$ report the unfortunate case of a man who sustained aortic graft perforation by the smoothened edge of a fractured rib that had not been closed. Despite a rapid return to the operating room, the patient died. The authors provide a comprehensive description of 7 other cases of graft perforation due to contact with either calcification or bone.

Although this complication is rare, it can certainly be catastrophic when it occurs. This series highlights the mechanical susceptibility of Dacron to friction from bone or calcifications, even when these are not sharp. Nonanastomotic primary aortic Dacron graft failure occurring between 13 and 22 years postimplantation has been described. $^{2}$ Primary graft failure in smaller-diameter vascular grafts has been reported as soon as 13 months postimplantation. ${ }^{3}$ Analysis of these long-term cases reveals broken polyester filaments. It follows that grafts subject to unusual mechanical stress in the form of friction due to an adjacent hard object may fail. These cases should raise awareness in aortic surgeons. Special attention must be given to ensuring secure chest wall closure, and posterior rib stumps must be managed either with careful reapproximation or placement of tissue between graft and bone.

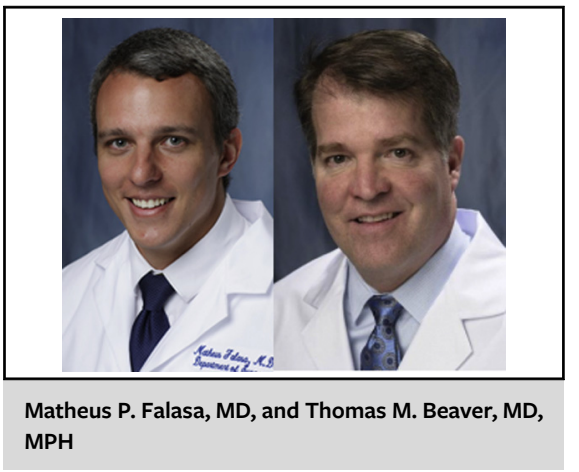

CENTRAL MESSAGE

Raising awareness of this rare but lethal complication may help surgeons avoid this complication. Fractured ribs should be carefully managed during any initial operation.

\section{References}

1. Ishii T, Iguchi Y, Tsukada T, Osaka M. Aortic graft perforation by a rib stump after thoracic aorta replacement: a case report and literature review. J Thorac Cardiovasc Surg Tech. 2021;8:40-2.

2. Aurigemma D, Borquez A, Lee J, Newberry R, Moore JW, Lamberti J, et al. Nonanastomotic failure of woven Dacron tube grafts in the thoracic aorta in young adults. J Card Surg. 2018;33:653-7.

3. Van Damme H, Deprez M, Creemers E, Limet R. Intrinsic structural failure of polyester (Dacron) vascular grafts. A general review. Acta Chir Belg. 2005;105: 249-55.

\footnotetext{
From the ${ }^{\mathrm{a}}$ General Surgery Residency Program and ${ }^{\mathrm{b}}$ Division of Cardiovascular Surgery, Department of Surgery, University of Florida, Gainesville, Fla.

Disclosures: The authors reported no conflicts of interest.

The Journal policy requires editors and reviewers to disclose conflicts of interest and to decline handling or reviewing manuscripts for which they may have a conflict of interest. The editors and reviewers of this article have no conflicts of interest.

Received for publication March 19, 2021; revisions received March 19, 2021; accepted for publication March 22, 2021; available ahead of print March 26, 2021. Address for reprints: Thomas M. Beaver, MD, MPH, Division of Cardiovascular Surgery, University of Florida, 1600 SW Archer Rd, Gainesville, FL 32610 (E-mail: thomas.beaver@surgery.ufl.edu).

JTCVS Techniques 2021;8:43

2666-2507

Copyright (C) 2021 Published by Elsevier Inc. on behalf of The American Association for Thoracic Surgery. This is an open access article under the CC BY-NC-ND license (http://creativecommons.org/licenses/by-nc-nd/4.0/).

https://doi.org/10.1016/j.xjtc.2021.03.023
} 